\title{
ANALISIS PENGARUH PEMBIAYAAN MUDHARABAH, MUSYARAKAH, MURABAHAH DAN NPF TERHADAP ROA (STUDI KASUS BPRS DI INDONESIA)
}

\section{ANALYSIS OF THE EFFECT OF MUDHARABAH, MUSYARAKAH, MURABAHAH AND NPF FINANCING ON ROA (CASE STUDY OF BPRS IN INDONESIA)}

\author{
Rahmi Edriyanti1a, Chairina ${ }^{2}$, Anita Khairunnisa ${ }^{3}$ \\ ${ }^{1}$ Universitas Islam Negeri Sumatera Utara, Jalan Williem Iskandar Pasar V Medan Estate \\ 2Universitas Islam Negeri Sumatera Utara, Jalan Williem Iskandar Pasar V Medan Estate \\ ${ }^{3}$ Universitas Islam Negeri Sumatera Utara, Jalan Williem Iskandar Pasar V Medan Estate \\ aKorespondesi: Rahmi Edriyanti, e-mail: rahmiedriyanti@gmail.com
}

\begin{abstract}
This study was conducted to analyze the effect of mudharabah, musyarakah, murabahah and Non Performing Financing (NPF) financing on the profitability of BPRS using the VAR/ VECM method. A series of analysis processes were carried out starting from the stationary data at the first difference level, passing the stability test with a modulus value below 1 percent at lag 8. In the optimum lag test, the FPE value was obtained at lag 1 . Furthermore there were 4 cointegration so VECM analysis can be performed. Short-term analysis of the ROA model in Indonesia shows that there are no variables that significantly influence ROA. Meanwhile, the long-term analysis of the ROA model shows that there are three variables that significantly affect ROA, namely the mudharabah, musyarakah and murabahah variables at the 5\% level. In general, from the IRF results it can also be concluded that the response of the ROA variable to the mudharabah, musharaka, murabahah and Non Performing Financing (NPF) variables as a whole is consistent with the theory. Meanwhile, based on the results of the FEVD, the variable that has a large contribution to ROA in Indonesia is NPF. Then followed by murabahah and mudharabah. As for musyarakah, it is still considered as a complement to Islamic banking financing. Keywords: Mudharabah, Musyarakah, Murabahah, Non Performing Financing (NPF), Profitabilitas (ROA)
\end{abstract}

\section{ABSTRAK}

Penelitian ini dilakukan untuk menganalisis pengaruh pembiayaan mudharabah, musyarakah, murabahah dan Non Performing Financing (NPF) terhadap profitabilitas BPRS dengan menggunakan metode VAR/ VECM. Serangkaian proses analisis dilakukan dimulai dari data sudah stasioner pada tingkat first difference, lolos uji stabilitas dengan nilai modulus di bawah 1 persen pada lag 8. Di uji optimum lag diperoleh nilai FPE nya di lag 1. Selanjutnya terdapat 4 kointegrasi sehingga analisis VECM dapat dilakukan. Analisis jangka pendek dari model ROA di Indonesia menunjukkan bahwa tidak ada variabel yang secara signifikan mempengaruhi ROA. Sementara itu, analisis jangka panjang dari model ROA menunjukkan bahwa ada tiga variabel yang secara signifikan mempengaruhi ROA, yaitu variabel mudharabah, musyarakah dan murabahah pada level 5\%. Secara umum, dari hasil IRF juga dapat disimpulkan bahwa respon variabel ROA terhadap variabel mudharabah, musyarakah, murabahah dan Non Performing Financing (NPF) secara keseluruhan konsisten dengan teori. Sementara itu, berdasarkan hasil FEVD, variabel yang memiliki kontribusi besar untuk ROA di Indonesia adalah NPF. Kemudian disusul murabahah dan mudharabah. Adapun musyarakah, masih dianggap sebagai pelengkap pembiayaan perbankan syariah.

Kata kunci: Mudharabah, Musyarakah, Murabahah, Non Performing Financing (NPF), Profitabilitas (ROA). 
Rahmi Edriyanti. 2020. Analisis Pengaruh Pembiayaan Mudharabah, Musyarakah, Murabahah dan NPF terhadap ROA (Studi Kasus BPRS Di Indonesia). Jurnal Nisbah $6(2): 63-74$.

\section{PENDAHULUAN}

Indonesia merupakan salah satu negara dengan mayoritas penduduk muslim terbesar di dunia. Banyaknya penduduk muslim ini menyebabkan adanya tuntutan untuk menggunakan jasa keuangan atau bank yang halal dalam memenuhi kebutuhan dalam bertransaksi. Halal maksudnya di sini yaitu tidak mengandung unsur riba dan prinsipnya sesuai dengan Al-Qur'an dan sunnah. Bank yang halal ini biasa di sebut dengan bank syariah.

Bank Syariah merupakan bank yang tidak memiliki konsep bunga seperti pada bank konvensional. Pada Bank Syariah, prinsip yang digunakan adalah bagi hasil. Perbankan syariah ini semakin eksis setelah diakui oleh pemerintah dengan lahirnya Undang-Undang No. 21 Tahun 2008 yang mengatur secara khusus tentang perbankan syariah. Salah satu tugas dari bank syariah adalah memberikan pembiayaan kepada masyarakat.

Pembiayaan pada bank syariah terbagi menjadi tiga jenis yaitu pembiayaan dengan prinsip bagi hasil (mudharabah dan musyarakah), pembiayaan dengan prinsip jual beli (murhabahah, salam, dan istisna) dan pembiayaan dengan prinsip sewamenyewa (ijarah dan ijarah muntahiyah bitamlik atau IMBT). Menurut Faradilla dkk, pembiayaan yang disalurkan inilah yang dapat meningkatkan profitabilitas bank syariah (Faradilla, 2017). Tingkat profitabilitas yang baik tercermin dari meningkatnya laba yang dicapai oleh bank itu sendiri.

Pembiayaan yang sering dilakukan pada perbankan biasanya adalah murabahah yang bersifat produktif, sedangkan untuk mudharabah dan musyarakah jarang dilakukan. Hal ini terjadi dikarenakan pembiayaan mudharabah dan musyarakah mempunyai resiko yang relatif tinggi, pendapatan keuntungannya tidak pasti dan pembiayaannya cukup rumit. Menurut Ali, pembiayaan murabahah yang mudah dimengerti oleh masyarakat, tidak memerlukan analisa yang rumit dan menguntungkan untuk pihak bank maupun nasabah (Ali, 2016).

Bank Pembiayaan Rakyat Syariah menyalurkan pembiayaan mudharabah musyarakah, dan murabahah. Ketiga pembiayaan ini biasanya memiliki risiko pembiayaan (financial risk). Risiko pembiayaan adalah potensi kerugian bagi bank yang terjadi ketika nasabah yang peminjam (debitur) atau nasabah yang menerima pembiayaan tidak dapat membayar kewajibannya kepada bank (Budiman, 2018). Indikator yang sering digunakan untuk mengukur tingkat risiko pembiayaan adalah rasio Non Performing Financing (NPF).

Tabel 1. Jumlah ROA, Pembiayaan Mudharabah, Musyarakah, Murabahah dan NPF Pada BPRS di Indonesia Pada tahun 2014 sampai dengan September 2019 (Dalam Persen)

\begin{tabular}{|c|c|r|r|c|c|c|}
\hline No. & Tahun & Mudharabah & Musyarakah & Murabahah & NPF & ROA \\
\hline 1. & $\mathbf{2 0 1 4}$ & 139,91 & 157,40 & 181,86 & 99,33 & 29,95 \\
\hline $\mathbf{2 .}$ & $\mathbf{2 0 1 5}$ & 142,95 & 159,87 & 183,27 & 113,71 & 26,66 \\
\hline 3. & $\mathbf{2 0 1 6}$ & 144,35 & 162,07 & 184,65 & 116,9 & 27,33 \\
\hline 4. & $\mathbf{2 0 1 7}$ & 142,77 & 162,97 & 186,37 & 124,75 & 28,87 \\
\hline $\mathbf{5 .}$ & $\mathbf{2 0 1 8}$ & 144,40 & 162,80 & 188,21 & 134,42 & 27,19 \\
\hline 6. & $\mathbf{2 0 1 9}$ & 109,56 & 123,34 & 142,22 & 78,83 & 22,35 \\
\hline
\end{tabular}

Sumber: Data diolah 
Dari tabel di atas, meskipun pembiayaan yang paling banyak diberikan pihak bank kepada masyarakat adalah pembiayaan murabahah, musyarakah dan mudharabah. Serta dari ketiga pembiayaan mengalami peningkatan setiap tahunnya. Hal yang perlu diperhatikan lebih serius ialah kualitas dari kolektabilitas cicilan yang diberikan oleh nasabah. Hal ini dapat terlihat dari nilai Non Performing Financing (NPF) yang setiap tahunnya mengalami peningkatan dan tidak ada penurunan. Sehingga, ROA cenderung mengalami penurunan di akhir periode (2019) walaupun sempat mengalami kenaikan tipis pada periode-periode sebelumnya.

\section{MATERI DAN METODE}

Kualitas kolektabilitas sendiri terbagi ke dalam lima bagian yaitu tingkat 1 lancar, tingkat 2 dalam perhatian khusus, tingkat 3 kurang lancar, tingkat 4 diragukan dam tingkat 5 macet (Surat Edaran BI Nomor 30/16/UPPB, 1998). Untuk akad murabahah, hal yang sangat dihindarinya yakni hingga ke tingkat 3 , karena apabila nasabah mengembalikan dana setelah 90 hari, tentu membahayakan kinerja bank. Begitu juga untuk akad mudharabah dan musyarakah, hanya saja tidak sehatnya bank terhitung lebih awal yaitu pada kualitas tingkat 2 atau pernah nunggak sekali dalam tempo kurang dari 90 hari. Mengingat, kedua akad ini sama- sama memerlukan prinsip trust yang sangat ketat dan jumlah pembiayaan yang relatif besar. Sehingga, kedisiplinan pembayaran wajib diterapkan agar pihak bank juga dapat bertanggung jawab memberikan nisbah bagi hasil yang relatif tinggi kepada nasabah yang menyimpan uangnya. Yang nantinya berdampak pada kepercayaan nasabah untuk menitipkan dananya kepada bank tersebut.

Ketika kolektabilitas selalu cenderung stabil pada tingkat 1, maka ROA yang dihasilkan akan tinggi pula yakni kemampuan perusahaan untuk memperoleh keuntungan tinggi. Besarnya ROA yang dihasilkan menunjukkan kinerja keuangan semakin baik, karena tingkat pengembalian (return) semakin besar. Dari uraian di atas, dapat dilihat bahwa banyak faktor-faktor yang dapat mempengaruhi ROA yaitu pembiayaan mudharabah, musyarakah, murabahah dan Non Performancing Financing (NPF).

Dengan demikian, penelitian ini akan membahas lebih lanjut tentang bagaimana signifikansi variabel pembiayaan mudharabah, musyarakah, murabahah dan Non Performing Financing (NPF), terhadap ROA dalam jangka pendek dan jangka panjang serta bagaimana respon variabel ROA terhadap variabel mudharabah, musyarakah, murabahah dan Non Performing Financing (NPF), serta seberapa besar kontribusi antar variabel.

\section{Return On Asset (ROA)}

Return On Asset (ROA) adalah salah satu dari beberapa rasio yang dapat digunakan dalam mengukur tingkat profitabilitas. Profitabilitas merupakan kemampuan perusahaan dalam memperoleh laba yang berhubungan dengan penjualan, total aktiva dan modal sendiri. Nilai profitabilitas menjadi ukuran dalam menentukan kesehatan suatu perusahaan (Simorangkir, 1987: 118).

2. Pembiayaan Mudharabah

Menurut Undang-Undang No. 21 Tahun 2008 tentang perbankan syariah, mudharabah merupakan akad kerjasama suatu usaha antara pihak pertama (shahibul maal) yang menyediakan seluruh modal dan pihak kedua (mudharib) sebagai pengelola, dengan pembagian keuntungan atas usaha yang dijalankan sesuai dengan kesepakatan yang terdapat dalam akad atau perjanjian, sedangkan untuk kerugiannya ditanggung sepenuhnya oleh pihak bank syariah kecuali jika pihak kedua melakukan 
kesalahan yang disengaja, lalai, atau menyalahi perjanjian (Mardani, 2014: 138).

3. Pembiayaan Musyarakah

Menurut Undang-Undang No. 21 Tahun 2008 tentang perbankan syariah, musyarakah merupakan akad kerjasama di antara dua pihak atau lebih untuk suatu usaha tertentu yang masing-masing pihak memberikan porsi dana dengan ketentuan bahwa keuntungan akan dibagi sesuai dengan kesepakatan, sedangkan kerugiannya ditanggung sesuai dengan porsi dana masing-masing.

4. Pembiayaan Murabahah

Murabahah merupakan akad jual beli antara bank selaku penyedia barang dengan nasabah yang memesan dan membeli barang, dengan ketentuan bahwa keuntungan yang diperoleh sesuai dengan kesepakatan. Di mana harga jual bank diperoleh dari harga beli dari supplier ditambahan dengan keuntungan yang diambil bank dan cara pembayaran serta jangka waktunya disepakati secara bersama, apabila dilakukan dengan cara angsuran.

5. Non Performing Financing (NPF)

Non Performing Financing (NPF) adalah rasio dari pembiayaan yang telah disalurkan namun bersifat kurang lancar (sub-istandart), diragukan (doubtful), dan macat (lost) (Rizky, 2008: 196). Pembiayaan bermasalah merupakan Pembiayaan di mana terjadinya cedera janji dalam pembayaran kembalian pembiayaan sesuai dengan perjanjian, sehingga terjadi tunggakan, atau adanya potensi kerugian yang dialami debitur di perusahaan, yang memiliki kemungkinan timbulnya resiko di kemudian hari bagi bank (Rivai, 2017: 447).

6. Hubungan Antar Variabel

a. Pembiayaan Mudharabah dan Return On Asset (ROA)

Pembiayaan mudharabah merupakan pembiayaan berdasarkan prinsip bagi hasil yang ada di perbankan syariah. Pembiayaan mudharabah yang dilakukan oleh bank syariah akan memperoleh pendapatan bagi hasil sesuai nisbah yang disepakati dengan mitra kerja/nasabah, yang dapat mempengaruhi besarnya laba yang diperoleh oleh bank syariah. Sehingga akan mempengaruhi profitabilitas perbankan syariah yaitu Return On Asset (ROA).

b. Pembiayaan Musyarakah dan Return On Asset (ROA)

Pembiayaan musyarakah merupakan pembiayaan berdasarkan prinsip bagi hasil yang ada di perbankan syariah. Di mana di dalam pengelolaan pembiayaan musyarakah lebih sulit dan biayanya juga lebih tinggi dari pada jenis pembiayaan lain, yang ada di perbankan syariah. Selain itu, pendapatan yang diperoleh dari penyaluran pembiayaan musyarakah tidak secara optimal diterima, akibatnya terjadi ketidak seimbangan terhadap biaya yang telah dikeluarkan. Sehingga laba yang diperoleh oleh perbankan syariah tidak optimal dan akan berdampak terhadap turunnya profitabilitas perbankan syariah yaitu Return On Asset (ROA).

c. Pembiayaan Murabahah dan Return On Asset (ROA)

Pembiayaan murabahah merupakan pembiayaan bersadarkan prinsip jual beli dan juga salah satu produk perbankan syariah yang paling. Pembiayaan murabahah sebagai salah satu komponen penyusun aset terbesar di dalam perbankan syariah, yang dapat menghasilkan pendapatan berupa margin. Dengan dihasilkannya margin dari pembiayaan murabahah tersebut, maka akan mempengaruhi besarnya laba yang diperoleh, sehingga akan 
meningkatkan profitabilitas perbankan syariah yaitu Return On Asset (ROA).

d. Non Performing Financing (NPF) dan Return On Asset (ROA) Non Performing Financing (NPF) merupakan rasio dari pembiayaan bermasalah yang terjadi di dalam perbankan syariah. Dampak yang terjadi akibat Non Performing Financing (NPF) adalah hilangnya pendapatan dari pembiayaan yang disalurkan. Sehingga mengurangi perolehan laba bank syariah dan berpengaruh terhadap profitabilitas bank syariah yaitu Return On Asset (ROA). Jadi semakin rendah tingkat NPF maka tingkat dari profitabilitas semakin meningkat karena semakin kecilnya risiko pembiayaan bermasalah yang ditanggung oleh bank syariah. Sebaliknya jika semakin tinggi tingkat NPF maka tingkat dari profitabilitas semakin menurun dan bank syariah akan kehilangan kesempatan untuk memperoleh laba.

\section{Metode Penelitian}

Data yang digunakan dalam penelitian ini adalah data sekunder berupa data time series bulanan pada periode Januari 2014 sampai dengan September 2019, yang di peroleh dari sumber resmi dari Statistik Perbankan Syariah Otoritas Jasa Keuangan. Kemudian, data tersebut diolah dengan menggunakan software Eviews 9. Untuk variabel operasional yang digunakan dapat dijelaskan pada tabel di bawah ini:

Tabel 2. Variabel Operasional

\begin{tabular}{|c|c|c|c|c|}
\hline Variabel & Deskripsi & Satuan Data & Waktu & Sumber Data \\
\hline ROA & Return on Asset & Persen & \multirow{5}{*}{$\begin{array}{c}\text { Januari 2014- } \\
\text { September } \\
2019\end{array}$} & \multirow{5}{*}{ SPS OJK } \\
\hline MUDHARABAH & $\begin{array}{c}\text { Pembiayaan } \\
\text { Mudharabah } \\
\text { yang diberikan }\end{array}$ & Milyar Rupiah & & \\
\hline MUSYARAKAH & $\begin{array}{c}\text { Pembiayaan } \\
\text { Musyarakah } \\
\text { yang diberikan }\end{array}$ & Milyar Rupiah & & \\
\hline MURABAHAH & $\begin{array}{c}\text { Pembiayaan } \\
\text { Murabahah } \\
\text { yang diberikan }\end{array}$ & Milyar Rupiah & & \\
\hline NPF & $\begin{array}{l}\text { Non Performing } \\
\text { Financing }\end{array}$ & Persen & & \\
\hline
\end{tabular}

Sedangkan untuk menganalisis data, penelitian menggunakan metode kuantitatif Vector Auto Regression (VAR). Analisis VAR dilakukan karena hasil estimasi yang ditampilkan lebih baik dibandingkan metode lainnya yang lebih rumit. Serta tidak diperlukannya memisahkan antara variabel eksogen dengan variabel endogen karena semua variabel dianggap sebagai variabel endogen (Basuki, 2017: 227). Secara umum ada tiga bentuk VAR yang digunakan yaitu:
1. Apabila data yang digunakan sudah stasioner pada tingkat level, maka bentuk VAR yang dapat digunakan adalah VAR pada tingkat level, yang mengindikasikan dapat menjelaskan dan mengestimasi hubungan jangka panjang antar variabel.

2. Namun, apabila data yang digunakan tidak stasioner pada tingkat level, maka data harus diturunkan pada tingkat pertama (first difference) yang menampilkan data selisih atau perubahan. Jika data stasioner pada tingkat first difference, 
maka selanjutnya data akan diuji kembali untuk melihat keberadaan kointegrasinya antar variabel. Pada saat diuji tidak ditemukan kointegrasi antar variabel, maka bentuk VAR yang dapat digunakan adalah VAR pada turunan pertama (VAR first difference). Tetapi, model VAR first difference ini hanya dapat mengestimasi hubungan jangka pendek antar variabel.

3. Apabila data yang digunakan tidak stasioner pada tingkat level, tetapi terdapat kointegrasi pada data level, maka analisis dapat dilanjutkan ke Vector Error Correction Model (VECM) dengan menggunakan data level. Model VECM ini akan dapat mengestimasi hubungan jangka pendek maupun jangka panjang antar variabel.
Analisis selanjutnya pada metode VAR/VECM yakni dapat diamati dari dua bentuk analisis utama yaitu Impulse Response Function (IRF) dan Forecast Error Variance Decomposition (FEVD). Dalam penelitian ini variabel yang dilogaritma natural adalah variabel Mudharabah, Musyarakah dan Murabahah. Akan tetapi di dalam mengolah data di Eviews, keterangan "LN" tidak dicantumkan. Sehingga, model persamaan untuk melihat pengaruh ROA terhadap variabel Mudharabah, Musyarakah dan Murabahah dan NPF adalah sebagai berikut:

$\begin{aligned} \text { ROAt }= & \alpha 0+\alpha 1 \operatorname{lnMUDHARABAHt}+\alpha 2 \\ & \text { lnMUSYARAKAHt }+\quad+\alpha 3 \\ & \text { lnMURABAHAHt }+\alpha 4 \text { lnNPFt }+ \\ & \varepsilon \mathrm{t}\end{aligned}$

HASIL DAN PEMBAHASAN

1. Hasil Uji Stationeritas

Tabel 3. Hasil Uji Stationeritas Data

\begin{tabular}{|l|r|r|r|r|}
\hline \multirow{2}{*}{ Variabel } & \multicolumn{2}{|c|}{ Level } & \multicolumn{2}{c|}{ 1st difference } \\
\cline { 2 - 5 } & t-stat & (prob ADF) & t-stat & (prob ADF) \\
\hline ROA & -3.477275 & 0.0150 & -3.479367 & $\mathbf{0 . 0 0 0}$ \\
\hline MUDHARABAH & 3.478305 & 0.3458 & -3.478305 & $\mathbf{0 . 0 0 0}$ \\
\hline MUSYARAKAH & -3.478305 & 0.0872 & -3.478305 & $\mathbf{0 . 0 0 0}$ \\
\hline MURABAHAH & -3.478305 & 0.1701 & -3.478305 & $\mathbf{0 . 0 0 0}$ \\
\hline NPF & -3.477275 & 0.6473 & -3.478305 & $\mathbf{0 . 0 0 0}$ \\
\hline
\end{tabular}

Dari tabel di atas dapat dijelaskan bahwasannya nilai probabilitas di tingkat level belum stasioner karena lebih besar dari 0,05 disemua variabel kecuali variabel ROA. Sehingga diperlukan uji pada 1st difference. Setelah di uji, hasilnya seluruh variabel sudah stasioner.

\section{Hasil Uji Stabilitas Model VAR}

Tabel 4. Hasil Uji Stabilitas Model VAR

\begin{tabular}{|c|c|c|}
\hline Model & Kisaran Modulus & Maksimum Lag \\
\hline $\mathrm{R}$ & $0.79966-0.992028$ & 8 \\
\hline
\end{tabular}

Menurut tabel 4, lag maksimal model VAR yang stabil untuk ROA di Indonesia pada lag 8 , dengan kisaran nilai modulus $<1$. Artinya dari hasil uji stabilitas VAR, model ROA sudah stabil. 


\section{Hasil Uji Optimum Lag}

Tabel 5. Hasil Uji Optimum Lag

\begin{tabular}{|c|c|c|c|}
\hline \multirow{2}{*}{ Lag } & \multicolumn{3}{|c|}{ ROA Indonesia } \\
\cline { 2 - 4 } & FPE & AIC & SC \\
\hline 0 & $4.98 \mathrm{e}-13$ & -14.13855 & $-13.96403^{*}$ \\
\hline 1 & $\mathbf{2 . 9 4 e - 1 3 *}$ & -14.66894 & -13.62177 \\
\hline 2 & $3.67 \mathrm{e}-13$ & -14.46449 & -12.54467 \\
\hline 3 & $4.18 \mathrm{e}-13$ & -14.38109 & -11.58863 \\
\hline 4 & $4.32 \mathrm{e}-13$ & -14.43652 & -10.77142 \\
\hline 5 & $4.99 \mathrm{e}-13$ & -14.44428 & -9.906532 \\
\hline 6 & $6.31 \mathrm{e}-13$ & -14.45352 & -9.043133 \\
\hline 7 & $8.30 \mathrm{e}-13$ & -14.55983 & -8.276791 \\
\hline 8 & $7.13 \mathrm{e}-13$ & $-15.30037 *$ & -8.144689 \\
\hline
\end{tabular}

Dari tabel 5 memperlihatkan bahwa lag optimum yang terpilih pada model ROA di Indonesia adalah pada lag satu.

\section{Hasil Uji Kointegrasi}

Tabel 6. Hasil Uji Kointegrasi

\begin{tabular}{|c|c|c|c|}
\hline \multicolumn{4}{|c|}{ ROA Indonesia } \\
\hline $\begin{array}{c}\text { Hypothesized } \\
\text { No. of CE(s) }\end{array}$ & $\begin{array}{c}\text { Trace } \\
\text { Statistic }\end{array}$ & $\begin{array}{c}0.05 \\
\text { Critical Value }\end{array}$ & Prob. $^{* *}$ \\
\hline None $^{*}$ & 204.3169 & 69.81889 & 0.0000 \\
\hline At most 1 $^{*}$ & 97.69359 & 47.85613 & 0.0000 \\
\hline At most 2 & 50.65150 & 29.79707 & 0.0001 \\
\hline At most 3 & 21.89329 & 15.49471 & 0.0047 \\
\hline At most 4 & 0.026013 & 3.841466 & 0.8718 \\
\hline
\end{tabular}

Pada tabel 6, hasil yang dapat dilihat ialah ditemukannya 4 kointegrasi antar variabel pada model ROA di Indonesia. Oleh karena itu, penelitian menggunakan model VECM dapat dilakukan, yakni pada analisis jangka pendek dan jangka panjang.

5. Hasil Uji VECM

Tabel 7. Hasil Estimasi VECM ROA di Indonesia

\begin{tabular}{|c|c|c|}
\hline \multicolumn{3}{|c|}{ Jangka Pendek } \\
\hline V & Koefisien & T-Statistics \\
\hline CointEq1 & - & {$[-2.52828]$} \\
\hline $\mathrm{D}(\mathrm{ROA}(-1))$ & - & {$[-1.39236]$} \\
\hline D(MUDHARABAH(-1)) & 0.003 & {$[0.00672]$} \\
\hline D(MUSYARAKAH(-1)) & 0.494 & {$[0.51783]$} \\
\hline D(MURABAHAH(-1)) & - & {$[-0.00168]$} \\
\hline $\mathrm{D}(\mathrm{NPF}(-1))$ & - & {$[-0.75514]$} \\
\hline \multicolumn{3}{|c|}{ Jangka Panjang } \\
\hline $\mathbf{V}$ & Koefisien & T-Statistics \\
\hline MUDHARABAH(-1) & 3.195 & [ 5.56959] \\
\hline MUSYARAKAH(-1) & - & {$[-5.40658]$} \\
\hline
\end{tabular}




\begin{tabular}{|l|c|c|}
\hline MURABAHAH(-1) & 1.305 & [ 2.40952] \\
\hline NPF(-1) & - & {$[-0.30989]$} \\
\hline
\end{tabular}

Signifikannya suatu variabel dalam mempengaruhi variabel lain apabila nilai t-statistic dari variable tersebut lebih besar dari t-tabel pada taraf nyata $5 \%(\alpha=5 \%)$ yaitu 1.99773 (t-statistic > 1.99773). Nilai t-tabel diperoleh dari jumlah sampel dikurangi dengan jumlah variabel, $\mathrm{n}=$ 69 maka df $=(69-5)=64$. Analisis jangka pendek pada model ROA di Indonesia menunjukkan bahwa tidak terdapat satu pun variabel yang secara signifikan mempengaruhi ROA. Hal ini menunjukkan bahwa terdapat koreksi kesalahan negatif, sehingga dapat dikatakan terdapat mekanisme penyesuaian jangka pendek untuk menuju keseimbangan jangka panjang.

Lebih lanjut, dalam hasil estimasi VECM pada model ROA di Indonesia menunjukkan bahwa terdapat koreksi kesalahan positif dan negatif, sehingga dapat dikatakan terdapat mekanisme penyesuaian jangka pendek untuk menuju keseimbangan jangka panjang. Analisis jangka panjang pada model ROA menunjukkan bahwa terdapat tiga variabel yang secara signifikan mempengaruhi ROA yaitu variabel mudharabah, musyarakah dan murabahah pada taraf nyata $5 \%$.

Variabel mudharabah mempunyai pengaruh positif terhadap ROA. Artinya, jika terjadi kenaikan pembiayaan mudharabah, maka akan menyebabkan peningkatan profitabilitas sebesar 3.195906 . Kondisi ini sesuai dengan teori yang menyatakan bahwa semakin besar pembiayaan mudharabah yang diberikan, tentu akan meningkatkan profit dengan syarat kualitas kolektabilitas selalu pada tingkat 1 . Namun, apabila kualitasnya sudah mencapai tingkat 2, BPRS perlu meninjau ulang dalam memberikan pembiayaan karena pemberian pembiayaan yang tinggi akan berisiko tinggi juga terhadap kinerja dari BPRS. Penelitian yang memperoleh hasil yang sama telah dilakukan oleh Ayunda (2015), Fitriyani et al (2019), Faradilla (2017), dan Emha (2014).

Variabel selanjutnya adalah musyarakah yang mempunyai pengaruh negatif terhadap ROA. Artinya, jika terjadi kenaikan pembiayaan musyarakah, maka akan menyebabkan penurunan profitabilitas sebesar -4.749353 . Kondisi ini sesuai dengan teori yang menyatakan bahwa semakin besar pembiayaan musyarakah yang diberikan, akan menurunkan profit. Dalam akad musyarakah ini sendiri memerlukan tingkat kepercayaan yang tinggi. Memberikan dana yang besar tentu akan membuat BPRS berhadapan pada risiko yang besar pula. Sehingga, langkah BPRS untuk memberikan dana yang relatif kecil adalah tepat untuk mempertahankan kualitas kolektabilitasnya agar selalu di tingkat 1. Penelitian yang menemukan hasil yang signifikan negatif adalah Nawawi et al (2018).

Terakhir, variabel signifikan yang dibahas adalah murabahah. Variabel ini berpengaruh positif terhadap ROA. Hal ini berarti, jika terjadi kenaikan pembiayaan murabahah, maka akan menyebabkan kenaikan profitabilitas sebesar 1.305378. Kondisi ini sesuai dengan teori yang menyatakan semakin tinggi pembiayaan murabahah maka akan semakin meningkatkan profitabilitas perbankan syariah. Namun, hal yang perlu diperhatikan adalah terus memantau kualitas kolektabilitasnya untuk selalu berada pada tingkat 1 atau 2. Apabila sudah tingkat 3, tentu akan membahayakan BPRS. Hasil penelitian yang sama dilakukan juga oleh Ayunda (2015), Fitriyani et al (2019), dan Faradilla (2017). 
6. Analisis Impulse Response Function (IRF)

a. Respon ROA terhadap guncangan variabel Mudharabah

Pada Gambar 6 dapat dilihat mengenai IRF bahwa ROA cenderung merespon positif terhadap guncangan variabel mudharabah hingga akhir periode ke-69 dengan standar deviasi 0,126027 meskipun di periode awal dan ke 42, 43, 46 sempat merepon negatif. Hasil IRF ini menunjukkan bahwa ketika terjadi guncangan pada variabel MUDHARABAH, maka ROA akan mengalami kenaikan. Hal ini dapat dijelaskan bahwa pembiayaan mudharabah berdampak laba perbankan BPRS. Semakin besar pembiayaan mudharabah yang diberikan, tentu akan memperbesar risiko untuk memperoleh laba yang besar. Risiko dapat saja terjadi tidak hanya di dalam bisnis it u sendiri, tetapi juga akibat faktor kecurangan maupun kelalaian dari nasabah.

b. Respon ROA terhadap guncangan variabel Musyarakah

Dalam kondisi yang hampir sama dengan poin a, variabel ROA merespon positif terhadap guncangan variabel musyarakah di periode awal dan dimulai dari periode ke 48 hingga akhir periode yang standar deviasinya sebesar 0,03667. Walaupun sempat merespon negatif di periode ke 5 dan 43. Hal ini menggambarkan bahwa ketika terjadi guncangan pada variabel MUSYARAKAH, maka ROA juga akan mengalami kenaikan. Maknanya, pembiayaan musyarakah yang tinggi akan berisiko besar terhadap jumlah profitabilitas yang diperoleh BPRS. Mengingat pengelolaan pembiayaan musyarakah lebih sulit dan biayanya juga lebih besar dari pada jenis pembiayaan lain, yang ada di perbankan syariah. Penelitian yang dianggap sejalan dengan pernyataan ini adalah penelitian Faradilla et al (2017) dan Emha (2014) yang menyatakan bahwa pembiayaan musyarakah berdampak positif terhadap profitabilitas perbankan syariah.

c. Respon ROA terhadap guncangan variabel Murabahah

Variabel ROA pada awalnya merespon negatif terhadap guncangan variabel murabahah yakni pada periode ke-4, 7 dan 41 . Lalu, secara bersama-sama dengan variabel mudharabah dan musyarakah meluncur di titik positif yang stabil hingga akhir periode dengan standar deviasi sebesar 0,037254. Hal ini menggambarkan bahwa ketika terjadi guncangan pada variabel MURABAHAH, maka ROA juga turut akan mengalami kenaikan. Maknanya, pembiayaan murabahah yang tinggi akan berisiko relatif tinggi terhadap jumlah profitabilitas yang diperoleh BPRS. Hasil ini sejalan dengan penelitian Ayunda (2015), Fitriyani (2019) dan Faradilla (2017).

d. Respon ROA terhadap guncangan variabel NPF

Variabel terakhir yang dibahas adalah respon variabel ROA terhadap goncangan variabel NPF di periode ke- 6 dan 17 merespon positif. Namun, dari ke 17 hingga periode terakhir terjun fluktuatif merespon negatif dengan standar deviasi akhir sebesar 0,204309. Hasil IRF ini menunjukkan bahwa ketika terjadi guncangan pada variabel NPF, maka ROA juga akan 
mengalami penurunan. Hal ini yang diharapkan oleh perbankan syariah karena semakin rendah tingkat NPF maka tingkat dari profitabilitas semakin meningkat karena semakin kecilnya risiko pembiayaan bermasalah yang ditanggung oleh bank syariah. Penelitian yang dengan hasil yang mirip dilakukan oleh Budiman (2018).

7. Analisis Forecast Error Variance Decomposition (FEVD)

Tabel 8. Ringkasan FEVD dalam model ROA di Indonesia

\begin{tabular}{|c|c|}
\hline $\begin{array}{l}\text { Kontribusi Guncangan Variabel } \\
\text { terhadap }\end{array}$ \\
\hline ROA NPF & \\
\hline $\mathbf{5 . 1 0 0 . 5 6 9}$ & \\
\hline MURABAHAH & 3.716 .237 \\
\hline MUDHARABAH & 1.595 .569 \\
\hline MUSYARAKAH & 1.414 .910 \\
\hline
\end{tabular}

Berdasarkan hasil FEVD di Tabel 8 , dapat dilihat bahwa variabel yang memiliki kontribusi besar terhadap ROA di Indonesia yang tertinggi adalah NPF. Kemudian diikuti oleh murabahah dan mudharabah. Sedangkan untuk musyarakah saat ini masih jarang digunakan oleh Bank Pembiayaan Rakyat Syariah (BPRS) di Indonesia. Kondisi ini menunjukkan bahwa BPRS sangat hati-hati dalam memutuskan untuk memberikan pembiayaan kepada nasabah. Hal ini disebabkan oleh ketidakdisiplinan nasabah dalam mengembalikan dana yang sudah diberikan oleh BPRS dan keadaan ekonomi yang tidak stabil yang menuntut nasabah tidak dapat mengembalikan dananya seperti inflasi, bencana alam dan wabah penyakit dunia seperti COVID-19 yang sedang dialami oleh dunia saat ini. Sehingga, hal ini berdampak pada kinerja bank. Akan tetapi, bank juga harus berani mengambil risiko besar yang terorganisir. Karena pada dasarnya BPRS memberikan kemaslahatan bagi umat.

8. Implikasi Kebijakan Secara Keseluruhan Yang Perlu Diambil Ke Depannya Oleh Bank Pembiayaan Rakyat Syariah (BPRS)

Adapun hal yang perlu ditekankan sebagai rekomendasi kebijakan yang perlu diambil oleh BPRS adalah perlu adanya dorongan yang lebih kuat untuk menerapkan pembiayaan mudharabah dan musyarakah, salah satunya dengan melakukan sosialisasi. Selanjutnya, pihak BPRS juga harus lebih berhati-hati dalam menyalurkan pembiayaan agar tidak terjadi pembiayaan bermasalah dengan cara meriset dan mengkaji terlebih dahulu potensi pasar dalam bisnisnya. Selanjutnya pihak BPRS harus monitoring atau mengawasi nasabah yang sudah melakukan pembiayaan dengan lebih ketat. Selain itu, bank perlu memperhitungkan risiko-risiko besar tak terduga lainnya yang akan dihadapi misalnya pandemi dunia yang seharusnya menjadi pertimbangan dan masuk ke dalam anggaran cadangan bank syariah. Hal ini berguna agar supaya BPRS senantiasa berada dalam status sehat dan dapat menjalankan fungsinya dengan baik.

\section{KESIMPULAN DAN IMPLIKASI}

Penlitian ini menganalisis pengaruh pembiayaan mudharabah, musyarakah, murabahah dan non performing financing (NPF) terhadap profitabilitas BPRS dengan menggunakan metode VAR/VECM. Serangkaian proses analisis dilakukan dimulai dari data sudah stasioner pada tingkat first difference, lolos uji stabilitas dengan nilai modulus dibawah 1 persen pada lag 8. Di uji optimum lag diperoleh nilai FPE nya di lag 1. Selanjutnya terdapat 4 kointegrasi sehingga analisis VECM dapat dilakukan. 
Analisis jangka pendek pada model ROA di Indonesia menunjukkan bahwa tidak terdapat satu pun variabel yang secara signifikan mempengaruhi ROA. Sedangkan, analisis jangka panjang pada model ROA menunjukkan bahwa terdapat tiga variabel yang secara signifikan mempengaruhi ROA yaitu variabel mudharabah, musyarakah dan murabahah pada taraf nyata $5 \%$.

Secara umum, dari hasil IRF dapat disimpulkan juga bahwa respon variabel ROA terhadap guncangan variabel pembiayaan mudharabah, musyarakah, murabahah dan non performing financing (NPF) secara keseluruhan sesuai dengan teori. Sementara itu, berdasarkan hasil FEVD, variabel yang memiliki kontribusi besar terhadap ROA di Indonesia yang tertinggi adalah NPF. Kemudian diikuti oleh murabahah dan mudharabah. Sedangkan untuk musyarakah saat ini tampaknya masih jarang digunakan sebagai pembiayaan perbankan syariah.

\section{UCAPAN TERIMA KASIH}

Kami mengucapkan terima kasih kepada Bapak Dr. Sugianto, MA selaku dosen mata kuliah Manajemen Risiko dan Bisnis Syariah pada semester ganjil tahun ajaran 2019/2020 yang sudah memberikan komentar membangun terhadap paper kami pada kesempatan ujian seminar tanggal 15 Januari 2020 yang lalu. Sehingga, kami dapat segera memperbaiki isi dari paper ini. Kemudian, kami juga berterima kasih kepada seluruh teman-teman seperjuangan di kelas Eksya A dan B 2018 yang saat ini kita sama-sama berjuang dalam menyelesaikan tesis. Semoga Allah selalu memberikan kemudahan bagi kita. Aamiin. Paper ini juga tidak luput dari kesalahan, sehingga diperlukan kritik membangun lainnya dari para pembaca.

\section{DAFTAR PUSTAKA}

Ali, Herni. "Determinan Yang Mempengaruhi Pembiayaan Murabahah Pada Perbankan Syariah". Jurnal Bisnis dan Manajemen. Vol. 06 No.01.

Arsana, I Gede Putra. 2004. VAR (Vector Auto Regressive). Jakarta: Laboratorium Komputasi Ilmu Ekonomi FEUI.

Ayunda, Revalia. 2015. Pengaruh Penyaluran Pembiayaan Mudharabah, Pembiayaan Musyarakah, Pembiayaan Murabahah dan Non Performing Financing (NPF) Terhadap Kinerja Bank Pembiayaan Rakyat Syariah Di Indonesia Periode Januari 2010 - Maret 2015. Jakarta: UIN Syarif Hidayatullah.

Emha, Muhammad Busthomi , 2014. "Analisis Pengaruh Pembiayaan Mudharabah, Musyarakah, Dan Ijarah Terhadap Kemampu Labaan Bank Muamalat Di Indonesia." Jurnal Ilmiah.

Basuki, Agus Tri, dan Nano Prawoto. 2017. Analisis Regresi dalam Penelitian Ekonomi dan Bisnis. Jakarta: PT. RajaGrafindo Persada.

Budiman, Rahmat, Noer Azam Achsani, dan Rifki Ismal. 2018. "Risiko Pembiayaan dan Determinannya pada Perbankan Syariah di Indonesia." Jurnal Aplikasi Bisnis dan Manajemen IPB Vol. 04 No.01.

Faradilla, Cut, Muhammad Arfan, dan M. Shabri. 2017. "Pengaruh Pembiayaan Musyarakah, 
Istishna, Ijarah, Mudharabah dan

Musyarakah Terhadap

Profitabilitas Bank Umum

Syariah Di Indonesia." Jurnal

Magister Akuntansi Unsyiah

Kuala Vol. 06 No. 03.

Fitriyani, Ana, Endang Masitoh, dan Suhendro. 2019. "Pengaruh Pembiayaan Murabahah, Mudharabah Dan Non Performing Financing (NPF) Terhadap Profitabilitas Bank Umum Syariah Terdaftar Di Bank Indonesia Tahun 2014 - 2017." Jurnal Widya Ganeswara Vol. 28 No. 01.

Mardani. 2014. Hukum Bisnis Islam. Jakarta: Kencana.

Rivai, Veithzal, dan et al. 2007. Bank and Finansial Institution Management: Coventional \& Syar'I System. Jakarta: Raja Grafindo Persada.

Rizky, Awalil, dan Nasyith Majidi. 2008. Bank Bersubsidi yang Membebani. Jakarta: EPublishing. Simorangkir. 1987. Dasar-Dasar Mekanisme Perbankan. Jakarta: Aksara Persada Indonesia. 